Linda S. Bluestein MD, Lawrence W. Stinson Jr MD, Robert L. Lennon Do, Stephen N. Quessy PhD, Rebecca M. Wilson

\title{
Evaluation of cisatracurium, a new neuromuscular blocking agent, for tracheal intubation
}

Purpose: The primary objective of this study was a blinded, randomized comparison of the recommended intubating dose of atracurium $\left(0.5 \mathrm{mg} \cdot \mathrm{kg}^{-1}\right)$ with an approximately equipotent dose of cisatracurium $\left(0.1 \mathrm{mg} \cdot \mathrm{kg}^{-1}\right)$ during $\mathrm{N}_{2} \mathrm{O}_{2} \mathrm{O}_{2} /$ propofol fentanyl anaesthesia.

Methods: Eighty. ASA physical status 1 or 2 patients, 18-70 yr of age, within $30 \%$ of ideal body weight, scheduled for elective low to moderate risk. surgical procedures were studied. Adductor pollicis evoked twitch responses were measured with a Grass FT 10 force displacement transducer (Grass Instruments, Quincy, MA) and continuously recorded on a Gould multichannel polygraph (Gould Instrument Systems, Cleveland, $\mathrm{OH}$ ) after induction of anaesthesia.

Results: Increasing the initial dose of cisatracurium (from 0.1 to 0.15 and $0.2 \mathrm{mg} \cdot \mathrm{k}^{-1}$, decreased mean time of onset (from 4.6 to 3.4 and $2.8 \mathrm{~min}$, respectively), and increased mean time of clinically effective duration $(45$ to 55 and 61 min, respectively). Recovery to a $T_{4}: T$, ratio of 0.7 occurred approximately seven minutes following administration of the reversal agent

\section{Key words}

ANESTHETICS, INTRAVENOUS: propofol;

INTUBATION: tracheal;

NEUROMUSCULAR RELAXANTS: atracurium, cisatracurium, $51 \mathrm{~W} 89$.

From the Department of Anesthesiology, Mayo Clinic, Rochester, MN, Department of Clinical Neurosciences, Burroughs Wellcome Co.Research Triangle Park, NC.

Sponsored by a grant from Burroughs Wellcome Co., Research Triangle Park; NC.

Address correspondence to: Dr. Robert L. Lennon, Department of Anesthesiology, Mayo Clinic $2001 \mathrm{St}$ SW, Rochester, MN 55905.

Phone: 507-284-8445. Fax: 507-284-5410.

Accepted for publication 5th May, 1996. neostigmine for all treatment groups. Intubation conditions were good or excellent in over $90 \%$ of patients in all treatment groups (two minutes after approximately $2 \times E D_{95}$ doses of cisatracurium or atracurium and 1.5 minutes after $3 \times$ and $4 \times$ $E D_{95}$ doses of cisatracurium).

Conclusion: The intubation results reported in this study together with the combination of predictable recovery from neuromuscular block and apparent haemodynamic stability make cisatracurium a potentially useful muscle relaxant in clinical practice.

Objectif: Comparer aléatoirement et en aveugle la dose d'atracurium recommandée pour l'intubation $\left(0,5 \mathrm{mg} \cdot \mathrm{kg}^{-1}\right)$ avec une dose approximative équipotente de cisatracurium $(0,1$ $\mathrm{mg} \cdot \mathrm{kg}^{-1}$ ) pendant une anesthésie associant $\mathrm{N}_{2} \mathrm{O}_{2} \mathrm{O}_{2}$ /propofoll fentanyl.

Méthodes: L'étude portait sur 84 patients ASA 1 et 2, agés.de 18 à 70 ans, dont le poids ne déviait pas de plus de $30 \%$ du poids idéal, programmés pour une chirurgie non urgente comportant un risque faible ou modéré. Le twitch évoqué à l'adducteur du pouce était mesuré après l'induction de l'anesthésie à l'aide d'un transducteur Grass FT 10 (Grass Instrument, Quincy; MA) et enregistré en continu sur un poly. graphe Gould (Gould Instrument System, Cleveland, $O H$ ).

Résultats: L'augmentation de la dose initiale de cisatracurium (de 0,1 à 0,15 et à $0,2 \mathrm{mg} \cdot \mathrm{kg}^{-1}$ ) diminuait l'installation du bloc (respectivement de 4,6 à 2,8 min) et augmentait la durée moyenne d'efficacité clinique (respectivement de 45 à 55 et.à $61 \mathrm{~min}$ ). La récupération à $0,7 \mathrm{du}$ rapport $T_{4} / T_{1}$ survenait environ sept minutes après l'administration de l'antagoniste néostigmine dans tous les groupes. Les conditions pour l'intubation étaient de bonnes à excellentes chez plus de $90 \%$ des patients de tous les groupes (deux minutes après des doses d'environ $2 \times E D_{50}$ de cisatracurium ou d'atracurium et 1,5 min après $3 \times$ et $4 \times E D_{50}$ de cisatracurium).

Conclusion: Les résultats rapportés dans cette étude concernant l'intubation associés avec un récupération prévisible $d u$ bloc au cisatracurium et sa stabilité hémodynamique apparente montrent que le cisatracurium pourrait être un relaxant musculaire utile en clinique. 
Nimbex $\dagger$ (cisatracurium besylate) Injection is a potentially useful new nondepolarizing neuromuscular blocking agent. Cisatracurium (previously referred to as 51 W89) is one of the ten isomers which constitute atracurium $^{1}$ and constitutes approximately $15 \%$ of the atracurium mixture. ${ }^{2}$ Cisatracurium is approximately three times as potent as atracurium with an $\mathrm{ED}_{95}$ of 0.05 $\mathrm{mg} \cdot \mathrm{kg}^{-1}$ during balanced anaesthesia. ${ }^{3,4}$ Like atracurium, cisatracurium is an intermediate-acting neuromuscular blocking agent which is assumed to undergo Hofmann elimination and ester hydrolysis and, therefore, would not depend upon renal or liver function for elimination. The principal advantage of cisatracurium is that there has been no evidence of histamine release at doses up to eight times the $\mathrm{ED}_{95}{ }^{5}$ whereas atracurium causes histamine release in humans at doses greater than $2.5 \times \mathrm{ED}_{95}{ }^{6.7}$

This study was conducted to evaluate the intubating conditions following intravenous administration of three doses of cisatracurium (two, three and four times the $\mathrm{ED}_{95}$ ) and atracurium (two times the $\mathrm{ED}_{95}$ ) during $\mathrm{N}_{2} \mathrm{O} / \mathrm{O}_{2} /$ propofol anaesthesia. The primary objective of the study was a blinded, randomized comparison of the recommended intubating dose of atracurium $(0.5$ $\mathrm{mg} \cdot \mathrm{kg}^{-1}$ ) with an approximately equipotent neuromuscular blocking dose of cisatracurium $\left(0.1 \mathrm{mg} \cdot \mathrm{kg}^{-1}\right)$. Additionally, we evaluated the neuromuscular blocking profile, rate of spontaneous recovery and efficacy of reversal.

\section{Methods}

Eighty ASA physical status 1 or 2 patients, $18-70 \mathrm{yr}$ of age, within $30 \%$ of ideal body weight, scheduled for elective low to moderate risk surgical procedures were studied. Patients who were pregnant, had a history of drug abuse, neuromuscular disorder or malignant hyperthermia, clinically important cardiac, renal, respiratory, hepatic or psychiatric disease were excluded. Patients recently exposed to antihistamines, tricyclic antidepressants, anticonvulsants or antibiotics were also excluded. Written informed consent was obtained from all patients and the study was approved by the Institutional Review Board.

\section{Anaesthetic management}

After placement of an intravenous catheter, automated sphygmomanometer and ECG leads, one arm of the patient was secured to a padded armboard and stimulation surface electrodes were applied to the ulnar nerve at the wrist. Most patients (71/80) were premedicated with 1-2 mg midazolam $i v$ in the operating room or preoperative holding area. General anaesthesia was induced with $2-2.5 \mathrm{mg} \cdot \mathrm{kg}^{-1}$ propofol preceded by $20 \mathrm{mg}$ lidocaine and $1.0-1.5 \mu \mathrm{g} \cdot \mathrm{kg}^{-1}$ fentanyl $i v$. Upon loss of consciousness, nitrous oxide $60-70 \%$ in oxygen was given by mask using a semiclosed system, and a propofol infusion was started at $10 \mathrm{mg} \cdot \mathrm{kg}^{-1} \cdot \mathrm{hr}^{-1}$. All patients lost consciousness at least three minutes before administration of the neuromuscular blocker. The investigators observed the patients conditions for indications of light anaesthesia e.g., tearing, lid reflex, swallowing, coughing, and gross skeletal movement. Anaesthesia was maintained with with $\mathrm{N}_{2} \mathrm{O}(60-70 \%), \mathrm{O}_{2}(30-40 \%)$, propofol infusion (initially at $10 \mathrm{mg} \cdot \mathrm{kg}^{-1} \cdot \mathrm{hr}^{-1}$ ), and supplemental fentanyl $\left(0.95-12.2 \mu \mathrm{g} \cdot \mathrm{kg}^{-1} i v\right)$ as needed. Following intubation the propofol infusion rate was adjusted as necessary $\left(0.6-15 \mu \mathrm{g} \cdot \mathrm{kg}^{-1} \cdot \mathrm{hr}^{-1}\right)$ to maintain the required level of anaesthesia.

\section{Monitoring of neuromuscular transmission}

Adductor pollicis evoked twitch responses were measured with a Grass FT 10 force displacement transducer (Grass Instruments, Quincy, MA) and continuously recorded on a Gould multichannel polygraph (Gould Instrument Systems, Cleveland, $\mathrm{OH}$ ) after induction of anaesthesia. Continuously throughout the procedure, supramaximal $0.2 \mathrm{msec}$ square wave stimuli (frequency of $2 \mathrm{~Hz}$ for $2 \mathrm{sec}$ ) in a train-of-four (TOF) pattern were delivered by a Grass $\mathrm{S} 88$ stimulator every ten seconds. The height of the first response to repetitive TOF stimuli is defined at $T_{1}$. The $T_{4}: T_{1}$ ratio is defined as the amplitude of the fourth twitch relative to the first twitch in a TOF stimulus.

The time of onset of neuromuscular block is defined as the time to maximum suppression of the $T_{1}$ response. The time to $25 \%$ recovery of the $T_{1}$ response is defined as the clinically effective duration of neuromuscular block. The rate of recovery is described by the recovery index, which is defined as the time from $25 \%$ to $75 \% \mathrm{~T}$, recovery.

\section{Clinical protocol}

After establishment of a stable baseline twitch response (three-five minutes), an intubating dose of atracurium or cisatracurium was injected over five seconds via a three-way stopcock inserted in the intravenous cannula. Immediately after the injection, the intravenous line was flushed by a rapid flow of fluid for $15 \mathrm{sec}$. Heart rate and arterial blood pressure were measured noninvasively each minute during the first five minutes after the initial dose.

The first 40 patients were randomized into two groups. Patients in group $\mathrm{A}(n=20)$ were given cisatracurium $0.1 \mathrm{mg} \cdot \mathrm{kg}^{-1}\left(2 \times \mathrm{ED}_{95}\right)$, and group B patients $(n$ $=20)$ received atracurium $0.5 \mathrm{mg} \cdot \mathrm{kg}^{-1}\left(2 \times \mathrm{ED}_{95}\right)$. Intubation was attempted two minutes after administration of the neuromuscular blocking agent. Group $\mathrm{C}$ and 
TABLE I Patient characteristics. There were no differences between the groups. Data are represented as mean \pm SD

\begin{tabular}{lccccc}
\hline & Group A & Group B & Group C & Group D & \\
& Cisatracurium & Atracurium & Cisatracurium & Cisatracurium & \\
& $0.1 \mathrm{mg} \cdot \mathrm{kg}^{-1}$ & $0.5 \mathrm{mg} \cdot \mathrm{kg}^{-1}$ & $0.2 \mathrm{mg} \cdot \mathrm{kg}^{-1}$ & $0.15 \mathrm{mg} \cdot \mathrm{kg}^{-1}$ & All patients \\
\hline Age (yr) & $39.2 \pm 12.0$ & $47.6 \pm 18.2$ & $37.6 \pm 17.0$ & $41.9 \pm 13.8$ & $41.5 \pm 15.6$ \\
Sex (M/F) & $10 / 10$ & $12 / 8$ & $12 / 8$ & $14 / 6$ & $48 / 32$ \\
Weight (kg) & $74.9 \pm 12.0$ & $72.5 \pm 12.2$ & $76.6 \pm 16.2$ & $81.7 \pm 15.6$ & $76.4 \pm 14.3$ \\
Height (cm) & $172.8 \pm 10.8$ & $170.6 \pm 10.3$ & $170.6 \pm 9.3$ & $176.7 \pm 11.5$ & $172.6 \pm 10.6$ \\
ASA Class (I/II) & $10 / 10$ & $6 / 14$ & $10 / 10$ & $9 / 11$ & $35 / 45$ \\
\hline
\end{tabular}

TABLE II Summary of time elapsed from initial propofol dose to intubation and total propofol dose before intubation

\begin{tabular}{llll}
\hline & & $\begin{array}{l}\text { Total propofol dose } \\
\left(\mathrm{mg}^{-1}\right)\end{array}$ & $\begin{array}{l}\text { Time from initial } \\
\text { propofol dose to } \\
\text { intubation }(\mathrm{min})\end{array}$ \\
\hline $\begin{array}{l}\text { Group A: cisatracurium } \\
\quad 0.1 \mathrm{mg} \cdot \mathrm{kg}^{-1}\end{array}$ & 18 & $3.13 \pm 0.08$ & $6.67 \pm 0.11$ \\
$\begin{array}{c}\text { Group B: atracurium } \\
\quad 0.5 \mathrm{mg} \cdot \mathrm{kg}^{-1}\end{array}$ & 19 & $3.15 \pm 0.07$ & $6.95 \pm 0.28$ \\
$\begin{array}{c}\text { Group C: cisatracurium } \\
0.2 \mathrm{mg} \cdot \mathrm{kg}^{-1}\end{array}$ & 19 & $3.09 \pm 1.3$ & $6.18 \pm 0.38$ \\
$\begin{array}{c}\text { Group C: } \mathrm{cisatracurium} \\
0.15 \mathrm{mg} \cdot \mathrm{kg}^{-1}\end{array}$ & 19 & $2.85 \pm 0.09$ & $5.61 \pm 0.45$ \\
\hline
\end{tabular}

*Data shown for patients in intubation score analysis. $\nmid$ Propofol dose is total of initial bolus plus amount infused up to the time of intubation attempt.

$D$ patients ( $n=20$ per group) were treated with cisatracurium $0.2 \mathrm{mg} \cdot \mathrm{kg}^{-1}\left(4 \times \mathrm{ED}_{95}\right)$ and $0.15 \mathrm{mg} \cdot \mathrm{kg}^{-1}$ $\left(3 \times \mathrm{ED}_{95}\right)$ respectively, and intubation was attempted after $1.5 \mathrm{~min}$. The intubator was blinded to the drug given in Groups A and B and the degree of neuromuscular blockade at the time of intubation (all groups). Because Groups C and D were added in an unblinded manner following completion of Groups A and B, it is difficult to make any comparisons between these treatment groups. In addition, the original intubator was no longer available during enrollment in Group D; therefore, in these patients the tracheas were intubated by a different anesthesiologist further making any direct comparisons among these treatment groups difficult.

Intubating conditions were rated grade $1-4$ :

1 Excellent. Easy passage of the endotracheal tube without coughing. Vocal cords relaxed.

2 Good. Passage of the tube with slight coughing and/or bucking. Vocal cords relaxed.

3 Poor. Passage of the tube with moderate coughing and/or bucking. Vocal cords moderately adducted.

4 Not possible. Vocal cords tightly adducted.

Following intubation, nitrous oxide and oxygen were continued via the endotracheal tube. To maintain the required level of anaesthesia, the propofol infusion rate was adjusted $\left(6-12 \mathrm{mg} \cdot \mathrm{kg}^{-1} \cdot \mathrm{hr}^{-1}\right)$ and supplemental doses of fentanyl were given. If surgery was prolonged, additional doses of cisatracurium $0.025 \mathrm{mg} \cdot \mathrm{kg}^{-1}(0.5 \times$ $\left.\mathrm{ED}_{95}\right)$ or atracurium $0.125 \mathrm{mg} \cdot \mathrm{kg}^{-1}\left(0.5 \times \mathrm{ED}_{95}\right)$ were administered when spontaneous recovery of $\mathrm{T}_{1}$ reached $5 \%$ of baseline levels.

In each group, patients were randomized to allow spontaneous recovery or pharmacological reversal. Reversal of residual neuromuscular block was initiated when spontaneous recovery of $T_{1}$ reached $10 \%$ of baseline levels and the surgical procedure was concluded or neuromuscular blockade was no longer required. Patients received neostigmine $45 \mathrm{~g} \cdot \mathrm{kg}^{-1}$ in combination with atropine $25 \mathrm{~g} \cdot \mathrm{kg}^{-1}$. Strip recordings for approximately three minutes beyond attainment of $95 \%$ recovery relative to baseline control (or return of $T_{1}$ response to a plateau height) and attainment of $a T_{4}: T_{1}$ ratio of 0.7 were used to determine the end-control for twitch height. All patients had a physical examination, haematology profile and measurements of serum creatinine, alkaline phosphatase and alanine aminotransferase preoperatively and within 24 to $48 \mathrm{hr}$ postoperatively.

\section{Statistical analysis}

Neuromuscular block data were compared among Groups B, C and D with a two-tailed, one-way Analysis of Variance. Differences between Groups A and B were analyzed with an unpaired t test. Intubation scores for Groups A and B were compared using the Mann-Whitney rank sum test. All analyses were performed on an IBM XT PC using Stat Pac statistical analysis package. Data in tables and text are expressed as mean \pm SEM, and statistical significance was defined by $P<0.05$.

\section{Results}

There were no differences in the mean age, height, or weight of patients among groups (Table I). With regard to depth of anaesthesia, all groups were comparable for the mean total dose $\left(\mathrm{mg} \cdot \mathrm{kg}^{-1}\right)$ of propofol administered prior to intubation and for the time elapsed between the initial propofol dose and beginning of the intubation attempt (Table II). Maximum block achieved exceeded 
TABLE III Intubation scores

\begin{tabular}{|c|c|c|c|c|c|c|c|c|}
\hline \multirow[b]{2}{*}{ Group } & \multirow[b]{2}{*}{ Drug } & \multirow[b]{2}{*}{$N$} & \multirow{2}{*}{$\begin{array}{l}\text { Intubation } \\
\text { dose } \\
\left(m g \cdot \mathrm{kg}^{-1}\right)\end{array}$} & \multirow{2}{*}{$\begin{array}{l}\text { Time to } \\
\text { intubation } \\
(\mathrm{min})\end{array}$} & \multicolumn{4}{|c|}{$\begin{array}{l}\text { No. of patients given } \\
\text { indicated intubating score }\end{array}$} \\
\hline & & & & & $\begin{array}{l}1 \\
\text { (excellent) }\end{array}$ & $\begin{array}{l}2 \\
\text { (good) }\end{array}$ & $\begin{array}{l}3 \\
(\text { poor })\end{array}$ & $\begin{array}{l}4 \\
\text { (not possible) }\end{array}$ \\
\hline A & Cisatracurium & 18 & 0.10 & 2 & 10 & 6 & 2 & 0 \\
\hline B & Atracurium & 19 & 0.50 & 2 & 14 & 5 & 0 & 0 \\
\hline C & Cisatracurium & 19 & 0.20 & 1.5 & 14 & 5 & 0 & 0 \\
\hline D & Cisatracurium & 19 & 0.15 & 1.5 & 11 & 8 & 0 & 0 \\
\hline
\end{tabular}

There were no statistically significant differences between groups A and B.

Intubation scores as described in text.

95\% in all patients and there were no clinically important haemodynamic effects before intubation. There were no failures to intubate due to inadequate muscle relaxation; intubation scores for five patients were excluded from the analysis. Two of the patients (both from Group A) were excluded due to mechanical problems with the laryngoscope which were not detected until the intubation attempt was started. These problems resulted in a prolongation of the intubation attempt outside of a reasonable window of time for the data to be included in an analysis of the intubation conditions at the specified times. The other three patients (one patient in each of the Groups B, C, and D) had anatomical problems that compromised the intubation attempt at the scheduled time. These problems were not able to be identified when the patients were screened. In all of these patients the tracheas were successfully intubated. Recovery data from eight patients were excluded because they received pharmacological reversal with $5 \%$ or $15 \%$ recovery of $T_{1}$. Flushing occurred in $2 / 20$ patients treated with atracurium and in $0 / 60$ patients treated with cisatracurium.

There were no differences in intubation scores in patients treated with equipotent doses of cisatracurium or atracurium (Table III). Conditions were excellent or good in 16 of 18 and poor in 2 of 18 patients in the two times $\mathrm{ED}_{95}$ cisatracurium group, and excellent or good in 19 of 19 patients in the atracurium group. The two patients who did not achieve good or excellent intubation conditions received all preoperative and induction medications as specified for this study. Onset times to maximum neuromuscular block, clinical duration of action (time to $25 \%$ recovery of $\mathbf{T}_{1}$ ) and recovery indices for all study groups are summarized in Tables IV and $V$. All patients achieved a maximum $T_{1}$ suppression of $100 \%$. Time to onset of maximum suppression was not different in patients treated with two times the $\mathrm{ED}_{95}$ atracurium or cisatracurium, although percent suppression of at intubation was considerably greater in the atracurium group, $81 \%$ versus $50 \%$. No differences were found for time to $5 \%$ spontaneous recovery, time to $T_{4}: T_{1}$ ratio $\geq 0.7$, or recovery index (time from $25 \%$ to $75 \% \mathrm{~T}_{1}$ recovery). In both groups within 12 minutes of administration of reversal agent, $T_{1}$ rapidly achieved $95 \%$ of baseline.

Overall, good or excellent intubation conditions were produced in $89 \%$ of patients two min following an initial dose of $0.1 \mathrm{mg} \cdot \mathrm{kg}^{-1}$ cisatracurium and in $100 \%$ of patients $1.5 \mathrm{~min}$ following an initial dose of 0.15 or 0.2 $\mathrm{mg} \cdot \mathrm{kg}^{-1}$ cisatracurium (Table III). Each cisatracurium group demonstrated differences in time to $90 \%$ block and maximum suppression, with more rapid onset occurring with increasing dose (Table IV). Increasing the initial cisatracurium dose of 0.15 or $0.2 \mathrm{mg} \cdot \mathrm{kg}^{-1}$ increased the duration of neuromuscular blockade by only 9.3 and $16.2 \mathrm{~min}$ respectively and the recovery profiles were similar and parallel to the time course of 0.1 $\mathrm{mg} \cdot \mathrm{kg}^{-1}$ cisatracurium (Figure 1). The time from injection of the initial dose to administration of the reversal agent depended on the time to reach $10 \%$ spontaneous recovery and was longer with high dose $\left(0.2 \mathrm{mg} \cdot \mathrm{kg}^{-1}\right)$, but was similar with the two lower doses of cisatracurium. Following pharmacological reversal, $95 \%$ recovery was rapidly achieved with similar and parallel results in all groups (Figure 2).

\section{Discussion}

In selecting a neuromuscular blocking agent to facilitate tracheal intubation or skeletal muscle relaxation an anaesthetist strives to achieve three competing goals: (1) rapid adequate muscle relaxation, (2) haemodynamic stability, and (3) predictable, complete return of skeletal muscle function. This study evaluated these three characteristics and, at equipotent doses, compared cisatracurium with atracurium. We evaluated intubation conditions as described by assigning an intubation score. There was no difference in intubation scores between groups receiving cisatracurium $0.1 \mathrm{mg} \cdot \mathrm{kg}^{-1}$ 
TABLE IV Onset and spontaneous recovery data

\begin{tabular}{|c|c|c|c|c|}
\hline & $\begin{array}{l}\text { Group A } \\
\text { Cisatracurium } \\
0.1 \mathrm{mg} \cdot \mathrm{kg}^{-1}\end{array}$ & $\begin{array}{l}\text { Group B } \\
\text { Atracurium } \\
0.5 \mathrm{mg} \cdot \mathrm{kg}^{-1}\end{array}$ & $\begin{array}{l}\text { Group C } \\
\text { Cisatracurium } \\
0.2 \mathrm{mg} \cdot \mathrm{kg}^{-1}\end{array}$ & $\begin{array}{l}\text { Group D } \\
\text { Cisatracurium } \\
0.15 \mathrm{mg} \cdot \mathrm{kg}^{-1}\end{array}$ \\
\hline \multicolumn{5}{|c|}{ Onset (min) } \\
\hline$-n$ & 20 & 20 & 20 & 20 \\
\hline - Mean & 4.6 & 4.0 & $2.8 * \dagger$ & $3.4^{*}$ \\
\hline - SEM & 0.3 & 0.3 & 0.1 & 0.2 \\
\hline - Range & $3.2-8.4$ & $2.0-6.8$ & $1.7-4.3$ & $2.0-5.5$ \\
\hline \multicolumn{5}{|c|}{ Duration (min) } \\
\hline$-n$ & 9 & 11 & 10 & 10 \\
\hline - Mean & 45.2 & 45.6 & $61.4^{*}$ & $54.5^{*}$ \\
\hline - SEM & 2.0 & 2.6 & 3.6 & 3.1 \\
\hline - Range & $33.9-51.3$ & $32.3-61.3$ & $40.5-80.9$ & $44.1-74.4$ \\
\hline \multicolumn{5}{|c|}{ Recovery index ( $\mathrm{min}$ ) } \\
\hline$-n$ & 9 & 11 & 10 & 10 \\
\hline - Mean & 13.4 & 12.8 & 13.3 & 13.0 \\
\hline - SEM & 0.9 & 0.7 & 0.8 & 0.4 \\
\hline - Range & $10.0-17.0$ & $8.8-16.5$ & $9.1-19.3$ & $11.4-15.9$ \\
\hline
\end{tabular}

Variables: onset $=$ the time to maximal depression of $T_{1}$ after injection of atracurium or cisatracurium; duration $=$ the time to $25 \%$ recovery of $\mathrm{T}_{1}$; recovery index $=$ the time from 25 to $75 \%$ recovery of $\mathrm{T}_{1}$. *Significantly different from cisatracurium $0.1 \mathrm{mg} \cdot \mathrm{kg}^{-1} \cdot(P<0.05)$.

†Significantly different from cisatracurium $0.15 \mathrm{mg} \cdot \mathrm{kg}^{-1}(P<0.05)$.

TABLE V Summary of recovery data after pharmacological reversal

\begin{tabular}{|c|c|c|c|c|}
\hline & $\begin{array}{l}\text { Group A } \\
\text { Cisatracurium } \\
0.1 \mathrm{mg} \cdot \mathrm{kg}^{-1}\end{array}$ & $\begin{array}{l}\text { Group B } \\
\text { Atracurium } \\
0.5 \mathrm{mg} \cdot \mathrm{kg}^{-1}\end{array}$ & $\begin{array}{l}\text { Group C } \\
\text { Cisatracurium } \\
0.2 \mathrm{mg} \cdot \mathrm{kg}^{-1}\end{array}$ & $\begin{array}{l}\text { Group D } \\
\text { Cisatracurium } \\
0.15 \mathrm{mg} \cdot \mathrm{kg}^{-1}\end{array}$ \\
\hline \multicolumn{5}{|c|}{ Time to reversal (min) } \\
\hline$-n$ & 9 & 6 & 5 & 7 \\
\hline - Mean & 41.6 & $31.3^{*}$ & $62.4 * \dagger$ & 48.6 \\
\hline - SEM & 3.0 & 3.6 & 3.3 & 4.5 \\
\hline - Range & $25.0-55.0$ & $19.0-44.0$ & $54.0-72.0$ & $30.0-68.0$ \\
\hline \multicolumn{5}{|c|}{ Time to $95 \%$ recovery $(\mathrm{min})$} \\
\hline$-n$ & 10 & 8 & 7 & 6 \\
\hline - Mean & 11.9 & 9.6 & 9.0 & 10.0 \\
\hline - SEM & 1.7 & 0.9 & 1.1 & 0.9 \\
\hline - Range & $7.4-21.9$ & $5.7-13.5$ & $4.9-12.8$ & $6.9-13.4$ \\
\hline \multicolumn{5}{|c|}{ Time to $T_{4}: T_{1} \geq 0.7(\mathrm{~min})$} \\
\hline$-n$ & 10 & 9 & 7 & 7 \\
\hline - Mean & 7.6 & 6.4 & 7.3 & 6.4 \\
\hline - SEM & 0.6 & 0.6 & 0.8 & 0.5 \\
\hline - Range & $5.3-11.1$ & $4.5-9.1$ & $4.6-10.1$ & $4.5-8.7$ \\
\hline
\end{tabular}

Variables: time to reversal $=$ the time interval between injection of atracurium or cisatracurium and administration of neostigmine; time to $95 \%$ recovery $=$ the time interval between injection of neostigmine and $95 \%$ recovery of $T_{1} ;$ time to $T_{4}: T_{1} \geq 0.7=$ the time interval between injection of neostigmine and $T_{4}: T_{1} \geq 0.7$.

*Significantly different from cisatracurium $0.1 \mathrm{mg} \cdot \mathrm{kg}^{-1}$.

$\dagger$ Significantly different from cisatracurium $0.15 \mathrm{mg} \cdot \mathrm{kg}^{-1}$.

and the recommended intubating dose of atracurium $\left(0.5 \mathrm{mg} \cdot \mathrm{kg}^{-1}\right)$. When the cisatracurium dose was increased to 0.15 and $0.2 \mathrm{mg} \cdot \mathrm{kg}^{-1}$, similar intubation conditions were produced $30 \mathrm{sec}$ earlier. Our data indicate that the vocal cords were relaxed and the tracheas of all patients could be intubated at two min following
$0.1 \mathrm{mg} \cdot \mathrm{kg}^{-1}$ cisatracurium (except for two patients whose vocal cords were moderately adducted) and at 1.5 min following 0.15 and $0.2 \mathrm{mg} \cdot \mathrm{kg}^{-1}$ cisatracurium. The difference between an intubation score of good or excellent was the occurrence of a slight cough or buck upon passage of the endotracheal tube. Scores of good or 


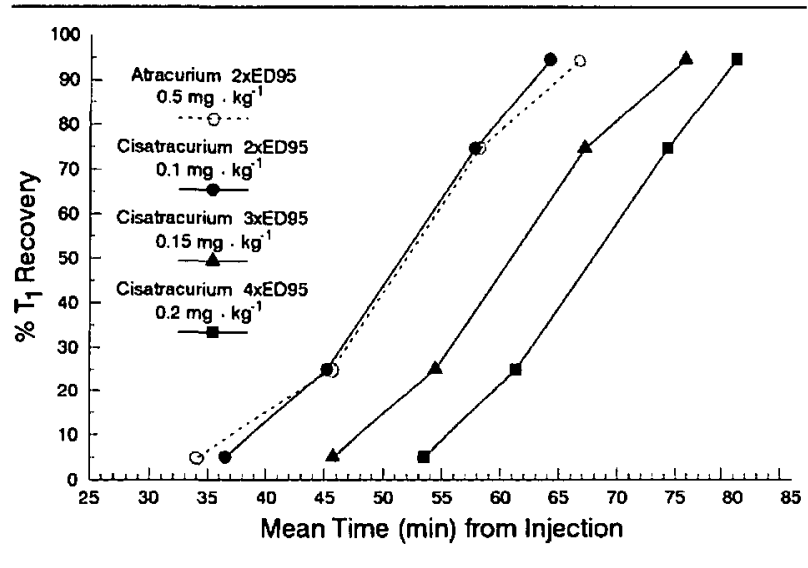

FIGURE 1 Spontaneous $T_{1}$ recovery following a bolus dose of atracurium or cisatracurium.

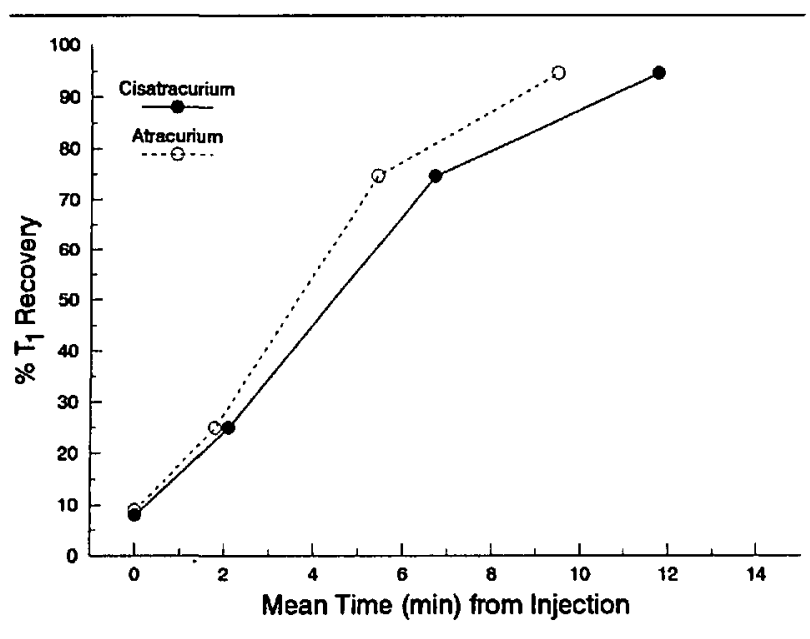

FIGURE $2 T_{1}$ recovery following pharmacological reversal.

excellent are considered indicative of clinically acceptable intubation conditions. As intubating conditions depend on the skill of the intubator and the depth of anaesthesia as well as on the degree of neuromuscular block, it is difficult to assess the relative merit of muscle relaxants based only on an intubation score. Therefore, neuromuscular block data were measured in this study.

Our results indicate that onset of neuromuscular block with cisatracurium, like other nondepolarizing agents, is more rapid with higher doses. An intubating dose of 0.1 $\mathrm{mg} \cdot \mathrm{kg}^{-1}$ produced maximum block in approximately $4.6 \mathrm{~min}$ with a clinical duration of $45 \mathrm{~min}$. This was comparable with an equipotent dose of atracurium $(0.5$ $\mathrm{mg} \cdot \mathrm{kg}^{-1}$ ). Doubling the initial dose of $0.2 \mathrm{mg} \cdot \mathrm{kg}^{-1}$ decreased the onset time to maximum block to $2.8 \mathrm{~min}$ and only increased the duration by $16 \mathrm{~min}$. Although there was a difference between equipotent blocking doses of atracurium and cisatracurium in percent sup- pression of $T_{1}$ at intubation, there was no clinical difference in intubating conditions and no difference in time required to complete intubation. There was poor correlation between intubation score and degree of neuromuscular block in most patients, which may be due to the difference in sensitivity to neuromuscular block and muscle flow at the adductor pollicis and the vocal chords or the diaphragm. ${ }^{8,9}$ If the dose is increased enough to suppress quickly the transmission at central muscle receptor sites, laryngoscopy and tracheal intubation can be successfully accomplished before the peripheral twitch is abolished.

In our study, there was a delay in administration of cisatracurium or atracurium after induction of anaesthesia because of the 3-5 min baseline strip recording required to assess neuromuscular function. This may have prejudiced the study toward poorer intubation scores than would be obtained clinically when intubation would be performed at a time when plasma and tissue levels of propofol would be higher and the depth of anaesthesia greater. Other sources of potential bias in this study include the non-randomized assignment of patients to the higher dose groups of cisatracurium, the fact that the intubator was not blinded in these two study groups, and that the intubator for the $0.15 \mathrm{mg} \cdot \mathrm{kg}^{-1}$ dose was different from that for the other groups. A further study evaluating intubation under conditions more closely resembling clinical practice, using a fully randomized and blinded design, is suggested.

Increased doses of all nondepolarizing muscle relaxants are found to decrease the time to onset of maximum neuromuscular block and prolong time to spontaneous recovery. $6,10,12$ Onset of block is decreased at the expense of prolonged duration. Atracurium, probably due to histamine release, produces pronounced hypotension at the high doses necessary to hasten onset. ${ }^{6.11}$ Lennon et al. ${ }^{13}$ reported attenuation of these cardiovascular effects with histamine receptor blockade although it appears that both $\mathrm{H}_{1}$ and $\mathrm{H}_{2}$ receptors must be blocked to be effective. Vecuronium can produce rapid onset of neuromuscular block with haemodynamic stability at doses up to eight to ten times the $\mathrm{ED}_{95}{ }^{12,14,15}$ but at the expense of unpredictable, excessive prolongation (up to $215 \mathrm{~min}$ ) of neuromuscular block ${ }^{16}$ and occasional difficulties in the reversal of block.

The data in Figure 1, which depicts the time-course of spontaneous recovery following doses of $0.1,0.15$, and $0.2 \mathrm{mg} \cdot \mathrm{kg}^{-1}$ cisatracurium compared with atracurium, suggests that once spontaneous recovery has begun, the time-course of recovery is independent of the dose of cisatracurium. Cisatracurium-induced neuromuscular block following doses of two to four times the $\mathrm{ED}_{95}$ was easily reversed and return of $\mathrm{T}_{1}$ to $95 \%$ recovery (mean 
$10 \mathrm{~min}$ ) and $\mathrm{T}_{4}: \mathrm{T}_{1}$ ratio to 0.7 (mean seven minutes) did not change with increasing initial dose. In addition, the data in this study show that the recovery profile following reversal of neuromuscular block induced by cisatracurium is similar to that following reversal of neuromuscular block induced by atracurium.

In summary, cisatracurium is an intermediate-acting nondepolarizing neuromuscular blocking agent. Tracheal intubation can be accomplished with adequate muscle relaxation two minutes after $0.1 \mathrm{mg} \cdot \mathrm{kg}^{-1}$ and $1.5 \mathrm{~min}$ following 0.15 and $0.2 \mathrm{mg} \cdot \mathrm{kg}^{-1}$. This increase in intubating dose hastened the onset of block and increased the clinical duration. Increasing the cisatracurium dose to $0.15 \mathrm{mg} \cdot \mathrm{kg}^{-1}$ increased the mean duration by only nine minutes, and doubling the dose from 0.1 to $0.2 \mathrm{mg} \cdot \mathrm{kg}^{-1}$ increased the mean duration by only $16 \mathrm{~min}$. Spontaneous recovery from cisatracuriuminduced neuromuscular block was found to proceed at comparable rates, once underway, after each of the three doses studied. The profile of recovery from neuromuscular block was similar for cisatracurium and atracurium. As with atracurium, dose-independent recovery may be the principal advantage of cisatracurium over vecuronium and rocuronium, although studies need to be conducted to confirm this. The principal advantage of cisatracurium compared with atracurium is the apparent lack of histamine release at large doses..$^{5,2}$ The rate of recovery of $T_{1}$ to $95 \%$ and $T_{4}: T_{1}$ ratio to 0.7 was rapid in each dosing group. The intubation results reported in this study together with the combination of predictable recovery from neuromuscular block and apparent haemodynamic stability make cisatracurium a potentially useful muscle relaxant in clinical practice.

\section{References}

1 Tsui D, Graham GG, Torda TA. The pharmacokinetics of atracurium isomers in vitro and in humans. Anesthesiology 1987; 67: 722-8.

2 Wastila WB, Maehr RB. The pharmacological profile of $51 \mathrm{~W} 89$, the R, Cis- R', Cis isomer of atracurium in cats. Anesthesiology 1993; 79: A946.

3 Belmont MR, Lien CA, Quessy S, et al. The clinical neuromuscular pharmacology of $51 \mathrm{~W} 89$ in patients receiving nitrous oxide/opioid/barbiturate anesthesia. Anesthesiology 1995; 82: 1139-45.

4 Lepage JY, Malinovsky JM, Malinge M,Cozian A, Pinaud $M$. 51W89: Dose-response, neuromuscular blocking profile and cardiovascular effects. Anesthesiology 1993; 79(Suppl 3A): A945.

5 Lien CA, Belmont MR, Abalos A, et al. The cardiovascular effects and histamine-releasing properties of $51 \mathrm{~W} 89$ in patients receiving nitrous oxide/opioid/barbiturate anesthesia. Anesthesiology 1995; 82: 1131-8.
6 Lennon RL, Olson RA, Gronert GA. Atracurium or vecuronium for rapid sequence endotracheal intubation. Anesthesiology 1986; 64: 510-3.

7 Siler $J N$, Mager JG $J r$, Wyche MQ Jr. Atracurium: hypotension, tachycardia and bronchospasm. Anesthesiology 1985; 62: 645-6.

8 Donati $F$, Meistelman $C$, Plaud B. Vecuronium neuromuscular blockade at the adductor muscles of the larynx and adductor pollicis. Anesthesiology 1991; 74: 833-7.

9 Pansard J-L, Chauvin M, Lebrault C, Gauneau P, Duvaldestin $P$. Effect of an intubating dose of succinylcholine and atracurium on the diaphragm and the adductor pollicis muscle in humans. Anesthesiology 1987; 67: 326-30.

10 Miller RD, Rupp SM, Fisher DM, Cronnelly R, Fahey $M R$ Sohn $Y J$. Clinical pharmacology of vecuronium and atracurium. Anesthesiology 1984; 61: 444-53.

11 Scott RPF, SavareseJJ, Basta SJ, et al. Clinical pharmacology of atracurium given in high dose. $\mathrm{Br} \mathrm{J}$ Anaesth 1986; 58: 834-8.

12 Tullock WC, Diana P, Cook DR, et al. Neuromuscular and cardiovascular effects of high-dose vecuronium. Anesth Analg 1990; 70: 86-90.

13 Hosking MP, Lennon RL, Gronert GA. Combined and receptor blockade attenuates the cardiovascular effects of high-dose atracurium for rapid sequence endotracheal intubation. Anesth Analg 1988; 67: 1089-92.

14 Ginsberg B, Glass PS, Quill T, Shafron D, Ossey KD. Onset and duration of neuromuscular blockade following high-dose vecuronium administration. Anesthesiology 1989: 71: 201-5.

15 Casson WR, Jones RM. Vecuronium induced neuromuscular blockade. The effect of increasing dose on speed of onset. Anaesthesia 1986; 41: 354-7.

16 Kaufman JA, Dubois MY, Chen JC, Lea DE. Pharmacodynamic effects of vecuronium: a dose response study. J Clin Anesth 1989; 1: 434-9. 